1917

Ja

Tames

Experiments or. Preservation and Ripening of Fruits 



\section{EXPERIMENTS ON PRESERVATION AND RIPENING OF FRUITS}

BY

WALTER P. JAMES

Pary

\section{THESIS}

FOR THE

DEGREE OF BACHELOR OF SCIENCE

IN

HORTICULTURE

COLLEGE OF AGRICULTURE

UNIVERSITY OF ILLINOIS 
Digitized by the Internet Archive in 2013

http://archive.org/details/experimentsonpre00jame 
1917
$J 39$

\section{UNIVERSITY OF ILLINOIS}

THIS IS TO CERTIFY THAT THE THESIS PREPARED UNDER MY SUPERVISION BY

\section{Walter P. James}

ENTITLED.... Experiments...n Preservation and Ripening of Fruits

IS APPROVED BY ME AS FULFILLING THIS PART OF THE REQUIREMENTS FOR THE

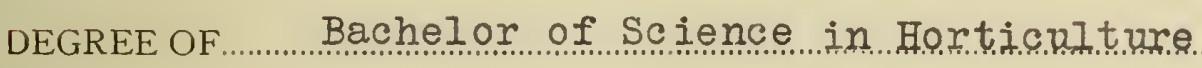

\section{Ifvinduncie}

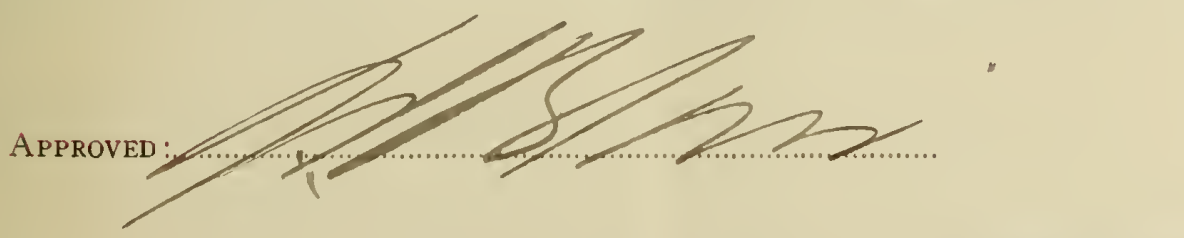

Instructor in Charge

HEAD OF DEPARTMENT OF ....Hor.ticulture 

The experimental : ork on the Preservation and Ripening of Fruits reported in this thesis was carried on under the direction of Dr. F. W. Kuncie and Prof. E. . . Bailey. The planning and carrying on of the laboratory work was under the supervision of Dr. luncie. 

Introduction............................ 6

I - COATING OF PEACHES WITH DIFREREIT MATERIALS . . . . 6

1.- Peaches immersed in olive oil..............

2.- Paraffin as a coating..................

3.- Effect of wrapping individual peaches..........10

4.- Use of disinfectants on rife perches............II

5.- Use of invertase and saccharose................2

6.- Oxggen as effectiro rate of decomposition.......13

7.- Hydrogen peroxide as a source of oxygen........15

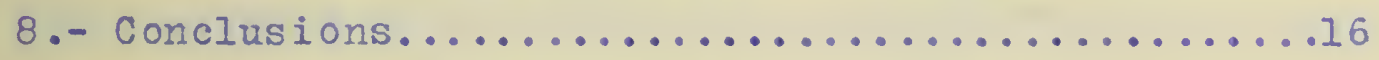

II - RESPIRATICN OF APPIES IN A CURRENT OF OXYGEN.....18 - 26

1.- Constant current of gas.....................

2.- Intermittant flow of gas.................22

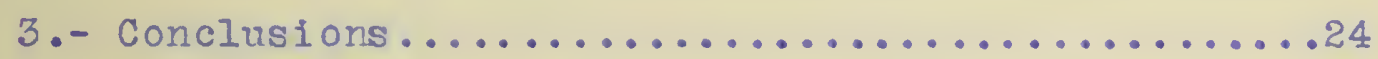

III - COLOR AID ITS CORREIATION WITH MFE ACIDIMY

1.- Vethod of extracting color................26

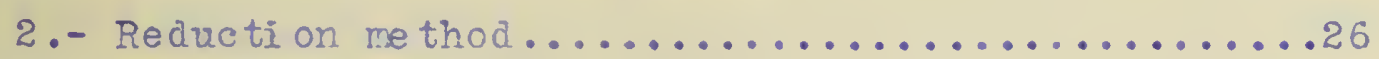

3.- rest for acidity of flesh..................

4.- Effect of drying on color of epiàermis........28

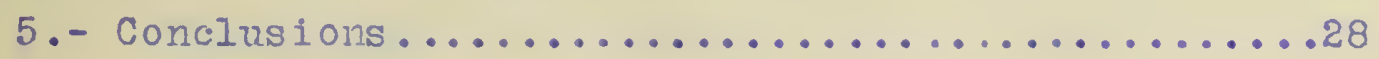

IV - EFFECT OF DRYIIG ON APPLES....................

1.- Effect of drying in light, dark and sunlight....31 

Eage

2.- Effect of drying upon acidity of flesh.........31

3.- Soaking in H2O before àrying...................

4.- Dipping in sugar and salt sol. before drying.....3

5.- loisture absorbing pover of aried apples.........34

6.- Dried apples in oil paper bass.................

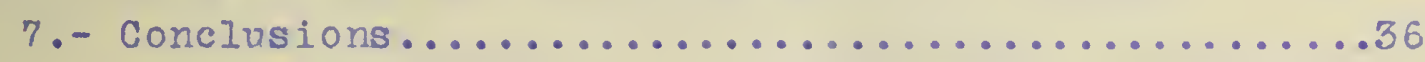

V. - BIBLIOGRAPHY................................. 44

VI. - DRANIHGS............................. 44

Key to figures............................

Fig. I. Respiration apparatus..............45

Fig. II.Cross section thru resp. apparatus........46

Fig. III. Drying apparatus ................4 



\section{EXPERIMENTS ON PRESERVATION AND RIPENING OF FRUITS}

The following work was carried on on peaches and apples in order to aetermine, if possible, the chemical and physiolor:cal offects of rarious treatments upon the fruits.

The experimental work may be josically dirided into four sections: SPCTION ONE - THE COATIIT AITD TREATITIT OF PEACHES WITH VARIOUS IATERIALS, UNDER VARYIIG CONDIMIONS AIND THE ETTECI UPON THE DECOIPOSITION OF THE PEACHES. In this work it was hope to find some method by which ripe peaches could be preverted from"breakirg down"so soon after kicking, thus prolonging the marketing of the peach crof. SECTIOI TWO - RESPIRAmION OF RIPE APPLES II AIT ATIOSPHERE OF OXYGEN, In this work the aim was to determine the effect of oxygen upon the rate of respiration of apples and to fina whether supplying an abunance of 02 by force ventilation of storage plants or refrigerator cars with air, woul counteract the value of forcea ventilation as a preventative of "ice scald" by increasing the breaking down of the fruits. SECTION THREE; COLOR AIN IT'S CORREIATION WITH THE ACIDITY OF AN APPIE. Is there a correlation betileen the percent of aciaity in the meat of an apple and the intensity of color of the epidermis? And does the lack of color developement in apples, within a variety, correspond with the difference in the acidity of the meat as compared with a highly colored apple of the same variety? SECTIOIN FOU? - 

EFFECT OF DRYING OR EVAPORATION UPON THE ACIDITY OF THE FLESH AID THE COLOR OF THE EPIDERIIS OF TIE APPLE. The aim was to preserve both the color of the epidermis and the color of the meat during the process of arying and also to find what effect àrying had on the acidity of the apple. 



\section{I - THE COATING OF PEACHES WITH DIFFERENT MATERIALS UIDER}

\section{VARYIITG CONDITIONS AND THE EFFECT UPON THE DECOMPOSITION}

The following work was done with the hope of getting some suggestions for further and more detailed work along the Iine of retarding or inhibiting, the sudden "breaking down" of ripe peaches. If some mechanical or chemical means couid be dereloped which would make the above possible, it would solve many difficult problems which confront the srower and com-

mission man today. The fruit could be left on the trees until Iully developed which woald ad to their flavor, size, color and beauty, thus eliminating the packing of fruit green and hard when they are to be held any length of time.

Due to the time that the work was taken up it was impossitie to obtain peaches except from the state of llow York which had been in cold storage for some time. Only the following brief data was obtainable on the Elbertas used: The porches were picked about september 15, 1916, and put in cold storage at Lockport. IN. Y. On oct. 15, they were shipped to Chicago and stored again. Oct. 18, three bushels were obtained from 7. H. J. Cavanaugh (Commission man) Chicago, being shipped in a refrigerator car to the University. In all, tinese peaches had been off the trees for over four weeks, had been in different storare houses and shippea some seven 

hundred miles.

The peaches were of medium size, uniform, and put up in bushel baskets without tiering or center post. They were hard and showed no signs of decomposition or fungous growths.

\section{I - PEACHES IMIERSED IN OLIVE OIL.}

A. OCI. 19 Some of the peaches were coated with raseline and immersed in olive oil. The container was left on the laboratory table at room temperature $\left(22^{\circ} \mathrm{C}\right)$. OCI. 20 Bubbles of $\mathrm{CO} 2$ were being slovly given off. OCT. 33 Rate of bubbling increased. OCT. 30 The epidermis of the peache had turned brown, except where the touched the container. NOV. 8 The entire surface of the peaches was dark brown in color. The meat was still hard and firm but the oil had penitrated thru the entire peach in every case. NOV. 10 Marked decomposition had set in and the meat was soft and mushy. Fermentation was also setting in.Due to the penitration of the oil into the fruit, it would be impossible to use oils beneficially in checking the decomposition of peaches.

\section{2 - PARAEFII AS A COATING TO PREVENT CONMACI TITH O2 OF THE AIR.}

Next a series was Ium using paraffin. The different melting points were obtained by mixing, in different proportions, liquid and solid parafin.

A. OCT. 19 Peaches were placed in a fruit jar with somesolia paraffin, the jar was sealed, the air pumped out and heat was 

applied to melt the parafin, the peaches were coated with the warm parafin by roljing ine jar. The melting point of the paraffin was about $32^{\circ} \mathrm{C}$. The far was kept in the ice box with ice in the same apartment as the peaches.

Dec. 18 . There was no apparent decomposition of the skeletor as the flesh was firm and the color of the meat and epidermis had changed but very little. There was a slight trace of alcohol present and a very bitter taste. The sugar content was high.

B. OCT. 19. Peaches treated as in part \& but the air was not exhausted. DEC.18 Condition was the same as the condition of the peaches treated in part_. C. OCT. 19. Peaches treated as in part A only no parafin was put on them. Decomposition soon started. DEC. 18 the peaches were rotten and mushy, high in alcohol and there was water in the bottom of the jar, being formed during the changes within the perch.

D. OCT. 19. Treated as in part C. only the air was exhausted after sealing. DEC. 18 The peaches were similar to those in part $\mathrm{C}$.

Thus the paraffin must have piayed at least an important part in the preservation of the tissues, it having undergone practically no change of skeleton in three months, when the peach was coated with paraffin. 

It might be well to note here that in the case of all the peaches coated with solid paraffin (rith a melting point above the room temperature), when cut around, the paraffin lifted off in halres, leaving the surface of the fruit clean. A. OCT. 19. Peaches were immersed in liquid paraffin and placed in the ice box. NOV. 18 The entire surface of the peaches was brown. DEC. 18 The outer one fourth of the peaches was soft and mushy while the inner portion was hard and firm and slightly bloached. The bitter taste, noted above, was present. There was also alcohol noted.

B. OCT. 19. Peaches were placed in the ice box after beirg immersed in semi-solid paraffin with a melting point of about 34 degrees C. NOV. 1. Enough C 02 had been given off by the peaches to force the paraffir and peach up out of the beaker. The whole paraffin and peach were pushed back into the beaker but of course the pressure was released for a time. DEC. 18 The peaches were very similar in condition to the ones treated with liquid paraffin. C. OCT. 19 Peaches were immersed in solid paraffin and kept in the ice box. NOV. 10 The CO2 given off had forced a small opening thru the bottom of the paraffin coat and had developed enough pressure to crack the bottom of the beaker. DEC. 18 The meat was firm and normal in color. There was a trace of alcohol and a high percent of sugar. accompanied by a bitter taste, the same bitter taste which was notea in all the peaches coated with paraffin. 

3.EFFECT OF WRAPPING EACH INDIVIDUAL PEACH.

It has long been maintained by most Pomologists that wrapping peaches with individual wrappers is not profitable as "ice scald" soon derelopes. Pears, also subject to "ice scald", in cold storag,, are successfully $\nabla r a p p e d$ and stored as are apples. In order to determine the effect of wrapping poaches, the following experiments were run.

Common apple wrappers were used to wrep some of the peaches which were kept with unwrapped peaches in the ice box. Some wrapped peaches were kept on the laboratory table with checks unwrapped. In no case was there any sign of "ice scald", tho the humidity was very high in the ice box at all times.

A. OCT. 19 Twelve peaches were wrapped and placed in the ice box. Nov. 9 Three showed signs of decomposition. Nov. $2850 \%$ were wilted but still edible, yellow and derk around the seeds.

B. OCT. 19 Twelve unwrapped peaches were placed in the ice box. NOV. 9 50\% were black and mushy. NOV. 16 AII were rotten and soft. The vrapped fruit after 20 days, had kept $80 \%$ better than the unwrapped peaches.

C. OCT. 19 Twelve peaches were wrapped and left on the table at room temperature. OCT. 25 One was breaking down rapidiy. OCT. 27 Three of the peaches had broken down. NOV. I All were "down", but not nearly as soft and rotten 

as the unwrapped were under the same treatment.

D. OCT. 19 Twelve peaches were left on the table, unwrapped, as a check with the wrapped ones. OCT. 23 One was rotten and the others were soft and deep ye11ow. OCT. 27 A11 were soft and rotten. Agnin, the wrepped had held up about $80 \%$ better than the unwrapoed.

From the above results, obtained with peaches wrapped and kept at room temperature and with peaches wrapped and kept in an ice box, in the same chamber with the ice where the moisture percent was very high, which is supposed to be one of the determining factors in the cause of" Ice scald:; there is evidence that wrapoing does not induce ice scald on cold storage peaches and that wrapping peaches prolongs the "holding up" of the fruit $80 \%$.

4 - USE OF DISINEECTANTS ON RIPE PEACHES.

Disinfectants were next used. Cotton was placed in the bottoms of the fruit jars then moistened with the disinlectant, peaches put in and the jars sealed. A checic was run by simply omitting a disinfectant and sealing the peaches in the jar. The cotton in one far was moistened with a $5 \%$ solution of formalin and the cotton in another with a $95 \%$ sol. of alcohol. At the end of seren days the iruit was examined. All were bady decomposed but the untreated jar was the only one which did not have a vigorous orowth of fungus on the fruit. The disinfectants had either not destroyed the fungi present 

When sealed up or the cells of the epidermis of the fruits were made more permeable by the penitration of the disinfectants and were more readily attacked by the few fungi present.

\section{5 - USE OF INVERTASE AND SACCHAROSE.}

Thatcher having stated that no invertase was present In apples and that oxidases alone were responsible for the carbohydrate changes, it was decided to try invertase and saccharose to see if any change in the rate of decomposition would be caused by them.

A. OCT. 19 Peaches were immersed in a $50 \%$ normal solution of invertase (Browne "Handbook of Sugar Analysis",page 669). OCT. 23 A deep brown color had dereloped. Nov. I (Examined). The tissues stood out aistinetly and the meat vas bleached. No odor could be detected except the odor characteristic of yeast. B. OCT. 19 Mreated as in A except the invertase had been boilea to inactivate the enzyme. OCT. 26 Broun spots were appearing on the peaches. OCI. 27 The peaches were badIy decomposed, the meat was bleached and tasted bitter. C. OCT. 19 Invertase was injected into the peaches with a hypodermic syringe. OCT. 25 The peaches were all rotten. The regions immediately around where the invertase was injected, broke down first. No signs of bacterial or fungous growth were present. By injecting the invertase into the peach, the rate of decomposition was increased.

D. OCT. 19 Treatment was the same as in part_A except that a 
10, sol. of saccharose was used instead of invertase. The rate of giving off $\mathrm{CO} 2$ was slightly faster than when invertase was usea as show by the increase in the amount of bubbles given off. The rate of decomposition was also increased more than in the invertase solution. By OCT. 25 the peaches were all rotten.

E. Apples were injected with invertase. The invertase was Injecteo into the apples in sereral places. Distilled water was injected into several apples in the same number of places and same amounts as was the invertase. After 2 week, the apples were cut open and examined. Thore was a marked difference between the condition of the apples injected with invertase and those injected with w ter. The reginns around where the invertase was introduced were all brown in color and maked changes had begun to take place. The regions around whore bi ntor was introduced shoved but little change, a slight drying of the cells had occured along the hole that the needle had made. I neither the apples injected with invertase nor with water had fungous or bacterial growth started.

6. - OXYGEN AS EFFECIIIG THE RATE OF DECORPOSIMION.

A. OCT. 23 Thirteen peaches were placed in a largedesiccator and the air was replaced by 02 . The desiccator was left on the laboratory table. After two days the H2S04 was removed from the a siccatras it was absorbing moisture and causing the peaches to wilt. Thedesiceator was arain filled with 02 . 

NOV. 9 Two peaches were wilted. IOV. 16 One peach was bady shriveleả and all were a àeep orange yellow. DEC. 18 The meat was the same shade of yellow as the epidermis in every case. There was a slight trace of alcohol and the meat had lost its flavor and was tasteless. The bitter taste present in the fruit coated vith paraffin, Wra lacking. The seeds were normally bright and the tissues of the meat had apparentIy undergone no decomposition. Immediately uwon exposure to the air, the epidermis and meat turned a dee broin.

The checks run with the peaches in the stmosphere of air broke down rapialy and were rotten in eight dnys. B. OCM. 21 Peaches were placed in a fruit jar, air replaced by 02, then sealed and put in the ice box. Another jar of peaches was sealed up with an atmosphere of air instead of 02. DEC. 18. Peaches in the atmosphere of 02 had not decomposed as bady as those in the atmosphere of air, the taste was less bitter, a smaller percent of alcohol had been developeà, and the color was not as dark.

C. OCM. 21 Two jars of peaches were treated as in B, then the jars were coated on the outside with paraffin ana lamp black in order to keer the fruit in the dark. No difference could be found between these and the ones in the uncosted jars except that the epidermis and meat of the feaches in the dark jars were slightly lighter in color.

D. OCT. 21 A series,treated as in B. Was left on the 

lahoratory table. The results were similar but the decomposition was much more rapid, due to the aifference in temperature. From the work with oxygen gas, it is evident that enclosing in an atmosphere of 02 does not increase the rate of the entire processes of decomosition but cecreases it or at least some phase of it. This checking of the rate of decomposition can not be attributed solely ta the presence of $\mathrm{CO} 2$ evolved by the fruit as the fruits enclosed in an atmosphere of air broke down much sooner thar those enclosed in the atmosphere of 02 .

7. - FYIPOGEI PFROXIDE AS A SOURCE OF OXYGEN.

The most striking results were obtained by the use of a $3 \%$ solution of hydrogen peroxide and H20 in proportion of 1 : 10 as a source of 02 . OCm. 19 Peaches were placed in a fruit jar and the solution of hydrogen peroxiaje and water poured orer them and the jar cealec. INOV. 19 No visible change in the peaches. INOV. 28 A small brown spot had appeared on the top peach where it was exposed to the air above the solution. When the top peach was examined, the marrin line of the spot was as marked in the meat as it was on the surface of the peach. DEC. 18 The uncier peaches were normal in color, blush, freshness of appearance, size and shape. The meat was firm and the origiral color and texture had been retained. The seeds were normal in color also. The only changes were a trace of alcohol and a bitter taste. 

8.COICIUSIOIS.

1. Peaches immersed in oils as olive oil aná vaseline, retained their firmness and structure much longer than whon untreated, but the oils readily peritrated the meat ana spoiled the quality of the perch.

2. Peaches coated with paraffin retained their color, firmess and structure as long as three months but in every case, alcohol had developea an present. Solid paraffin did not adhere to the epidermis of the fruit but pealed off nicely. In all probability, the use of paraffin as a preservative for fresh peaches is mace impossible by the preserce of the bitter taste in perches treated wi th paraffin. Solid paraffin with a high melting point gave results better than the lower melting paraffin.

3. The theory that wrapping peaches individually caused increase in "ice scald" and thus vas impracticable, was disproven. Trapping peaches from a commercial standpoint, would pay both for consumption on the market at picking time and for storage under normal conditions, regaraing cost of labor and paper, etc. The rate of decomposition or "breaking down" was decreasea $80 \%$ both with the peaches in the ice box and at room temperature. Thus, if used comercially, wraping would increase the time of "holding up" of a ripe peach on the market from $4-5$ days to $16-20$ days.

4. No beneficial results were obtained by the use of aisinfec- 

tants, as the fungi developed resdily on the fruits treated with the different disinfectants. This does not signify that disinfecting peaches before basketing would not pay commercially as, in the above work, the atmosphere around the peaches was saturated. Wi th the disinfectants and ma have effected the structure of the cells of the epidermis and made them less resistant to the attack of bacteria and fungi.

5. Invertase and snahrose increased the rate of change within the peach

6. Oxgeen supplied to reaches, both in the form of gas ara in H202, decreased the rate of decomposition to a marked iegree. The taste characteristic of the eaches coated ith paraffin, was lacking tho alcohol and an unosirable taste ceveloped when the peaches began to "break down" in the atmosphere of 02 . 7. Coating of pecches reserved the skeleton for a short period. Oxtgen retaras the rate of change but does not retarò the "breaking down" of the structure of the peach as does conting, inaicating that 02 acts difforently on the decomposition than does CO2 held in by the coating.

8. Whe erzrotic changes within the gan are ront entirely controllable bye treatmert usea but can be noticeably

retarded by the use of an atmosphe re of 02 or a solution of $\mathrm{H}_{202}$. 9. The best results were obtained when H202 was used. By the use of H202 all phases of the processes of decomposition vere controlled except the developement of a bitter taste. 
II RESPIRATION OF APPIFS IN A CURPEIT OF OXYGEN.

From the work with peaches in an atmosphere of oxygen and in H202, it was found that there was a marked wecrease in the rate of "breaking down", especially in the skeletor of the fruit. If the rate of decomposition is associated with the rate of respiration then the atmosphere of 02 should either increase the rate of respiration and decomposition or decrease both, provided, that respiration depends upon the supply of 02 frow the air in the production of even part of the C02, given off auring the process of respiration. By setting up a suitable apparatus where by 02 could be passed over a known amount of fruit, in a reoular flow and the co2 given off by the fruit carried with the escapino 02 and weighed at regular intervals, the effect of 02 on respiration cocli be determined accurately; thus the following experiments were conducted: Apples were used because no other fruits as perches, etc., could be obtrined, due to the lateness of the season. The apparatus was designed and set up so that it may be used for various gases and different fruits and vegetables. The apparatus wis built so that a constant flow of ges coula be passed thru the respiration chambers (cortaining the $f r(t)$ and rearly a constant temperature varying not more than $\frac{1}{2}$ " during an entire"run", maintainec at all times in the chamber. Figure I shows the entire apfaratus and Figure II shows a cross section thru the apparatus. 

Constant pressure was obtained in the gas bottles $B$ \& Blig. I by means of the tro constant level bottle $A$ \& $A$ " fig. I. The in-flow of tap water into the constant level bottles being slightly greater than the out-flov into the gas bottles, there was a continual over flow into the drain tube and thereby the height of the water was always the same, giving constant pressure in the gas bottles. To aroid refilling at such short intervals, 40 1. bottles were used for the gas. From the large bottles, the gas frssed into bottles C \& C' Fig. I where C02 was removed by bubbling thru sodium hydroxide solution. Next the gas was washed by bubbling thru water in the wash bottles I \& I' fig. I . From the wash bottle the gas passed into the respiration chambers thru incividual tubes with olass stopcoclis to regulate the rate of 1 low, the gas being introduced at the bottom of the chamber and. taken off at the top. From the respiration chamber the gas passed thru water traps illustrated by T,fig. II. Next it was led thru a U tube of calcium chloride to remove traces of moisture before entering the potash bulbs where the CO2 was absorbed. The walls of the U tubes were greased with vaseline in order to prevent sealing up by the calcium chloride upon taking up moisture. The bulb yas of the Iiebig type ana had a small calcium chloride tube ground on, in which was wut, next to the bulb, crushed potash to absorb co2 not taken up by the solution in the bulb, and lastly calcium chloride was placed in the bulb of the grouna-on tube to catch any excess moisture that might 

be swept thru the potash bulbs with the escaping air and oxygen. Glass wool was used where porous stoppers were needed, othemise rubber stoppers were used. All connections were mac mith the ends of the glass tubing as close as possible, rubber tubing was wired and all connections, where wossible, were sealed with Canada balsam. The stoppers wore wired and sealed. The dociccators, used for respiration chambers, were held in place and frevented from rising in the water bath bo means of the rods as shown in fig. II $\mathrm{K}$. The constant temperature bath consisted of a galvanized tank $45 \mathrm{in}$. by $14 \mathrm{in}$. wide by $10 \mathrm{in}$. deep. A thermometer was suspendea in the bath at each end of the tark. The witer from the heating tank ras introduced at the bottom of one ena by means of a small rotary uump, driven by a motor. The water was taken off at the top and opposite end and returned to the heater by gravity. The motor furnished the forer which ran the pump also propelied a small agitator in the heating tank which kept a more nearly uniform temperature there-in. At no time did the temcerature of the bath vary more than $\frac{1}{2}$ C during the entire "run" of a series. The temperature was controlled by a mercury termo-rearlator which reoulated the flow of gas to the burner under the herter, fig. I,N. Part of the sapply of gas was piped directly to the burner, as indicated by the arrows in fig. I, the remainder passed thru the h termarepulator. By the expansion or contraction of the colum of mercury, this supply was cut down or increased, thus retarding 

or increasing the heat given off by the burner under the heating tank.

The temperature was regulated to $3 \mathfrak{2}^{0} \mathrm{C}$ in the bath tank. The bubbles were regulated to approximatelt 40 per minute. At the start of each series, or run, the fruit was placed in the respiration chambers ano allowed to remain there as the temperature of the bath came to $320 \mathrm{C}$. Air was forced thru all the respiration chambers for from 4 to 6 hours to srieen out all the excess 022 , then 02 was substituted for air in the three chambers with ood numbers $(1,3$ and 5$)$, the bulbs were connected and after regulating the rate of flow of the bubbles of air and 02, the bulbs were weighed and the weights recorded. The potash bulbs were removed and weighed at intervals of 12 hours as nearly as possible. The ground-on calcium chloride tubes were reighed with the bulbs. The bulbs were kept covered with cheese cloth to prevent dust from settling on them.

$1=$ CONSTAITT CURREIT OF GAS TABLEI. WIILOW MWIG APPLES (Constant flow of gas) Willow twig apples, small ara bruised, cold storage apoles. The figures are on the basis of grams CO2 per hr. per 100 grams of fruit.

\section{FOUPS}

STARMIITG

16 hrs.

25 "

40 "

48 "

$63 "$

72 "

72

\begin{tabular}{|c|c|c|c|c|}
\hline OXYGEII & & & AIR & \\
\hline 1. & 3. & & 2. & 4. \\
\hline $\begin{array}{l}\text { TGrams } \\
.0079 \\
.0048 \\
.0046 \\
.0030 \\
.0057 \\
.0020\end{array}$ & $\begin{array}{r}\text { fer hr. } \\
.0078 \\
.0046 \\
.0038 \\
.0037 \\
.0054 \\
.0010\end{array}$ & & $\begin{array}{l}100 \text { gm. ruit) } \\
.0062 \\
.0034 \\
.0053 \\
.0045 \\
.0049 \\
.0016\end{array}$ & $\begin{array}{l}.006 \% \\
.0034 \\
.0053 \\
.0044 \\
.0049 \\
.0016\end{array}$ \\
\hline
\end{tabular}

Numbers 5 and 6 were lost. 

From the above table it is shown that the average rate of respiration per hour per. 100 grams of fruit is .00371 in the atmosphere of 02 and. 00259 in the atmosphere of air. Showing an increase caused by the atmosphere of oxygen.

TABLE II. VIIIE SAP APPIES (Constant current of O2)

(Wine sap apples ITo. 88 in perfect condition)

TINE.

\begin{tabular}{|c|c|c|c|c|c|}
\hline \multicolumn{3}{|c|}{ OXYGEII } & \multicolumn{3}{|c|}{ AIR } \\
\hline 1.10 & $\begin{array}{l}\text { er hr. } \\
.3 \text {. } \\
\end{array}$ & $\begin{array}{c}\text { er } 100 \\
5 . \\
\end{array}$ & $\begin{array}{l}\text { uit.) } \\
2 . \\
\end{array}$ & 4. & 6. \\
\hline $\begin{array}{r}0240 \\
00288 \\
0315 \\
0409 \\
0932 \\
0465\end{array}$ & $\begin{array}{l}.00659 \\
.00162 \\
.00399 \\
.00184 \\
.00758 \\
.00516\end{array}$ & $\begin{array}{l}.00484 \\
.00391 \\
.00377 \\
.00486 \\
.00334 \\
.00225\end{array}$ & $\begin{array}{l}.00365 \\
.00329 \\
.00298 \\
.00275 \\
.00331 \\
.00306\end{array}$ & $\begin{array}{l}.00424 \\
.00332 \\
.00510 \\
.00360 \\
.00348 \\
.00328\end{array}$ & $\begin{array}{l}.005 \\
.003 \\
.00 \\
.003 \\
.003\end{array}$ \\
\hline
\end{tabular}

With the wire saps in this series, the rate per gram per $100 \mathrm{gm}$. fmit per hour averaged,.00410,.00457, and .00471 for the ones in oxygen and .00312, .00375 and .00360 for the air, showing again that 02 increases the rate of resuiration of ripe apples.

2.- INTERIITTANT CURPENT OF GASES.

TABIE III. WINE SAP APPLES (Intermittant flow of gas)

Wine sap apples from the same box as those usec in

series II were used. In this series, the air and gas were passed thru in an almost continuous flow for one hour then the resuiration chambers were closed up and allowed to stand for six hours when the bulbs were weighed rna replaced, air and gas being run thru for another hour. This was repeated for ten periods with 

the following results:

PERIOD.

\begin{tabular}{cc} 
& OXYGEI. \\
\hline 1. & Grams per hr.pe \\
\hline .00104 & .00736 \\
.00781 & .00593 \\
.00661 & .00646 \\
.00534 & .00586 \\
.00518 & .00528 \\
.00525 & .00521 \\
.00518 & .00515 \\
.00197 & .00230 \\
.00186 & .00290
\end{tabular}

$100 \frac{\text { AIR. }}{\text { gmit) }}$

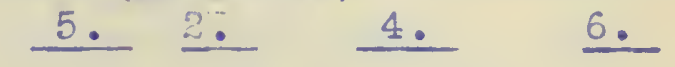

.00831 .00761 .00775 .00572 $.00612 .0059 \quad .0053 \quad .00431$ $.0059 \quad .0053 \quad .00523 \quad .00396$ .00527 .00321 .00524 .0036 $.00523 .00427 .0039 \quad .00384$ .00536 .00351 .00354 .00336 $.00538 .00406 \quad .00427 .00313$ .00231 .00173 .00184 .00138 .00253 .00176 .00185 .00163

The averages run .00535, .00530, and .00534 for the ones in oxygen and .00446,.00450 and .00320 for those in the atmosphere of air. Showing that the rate of respiration again increase $\bar{a}$ when in 02 .

Altho the increase in the rate of respiration, as determined by the amount of $\mathrm{CO} 2$ given off, increased arounc $25 \%$ where the wine saps were in an atmosphere of 02 , both constant flowing and intermittant, no increase in the rate of decomposition of the epidermis or flesh was noted, as compared with the ones run in the atmospheres of air.

Comparing the results of the above work with 02 with the work done with 02 in the first section of this report, it will be founo that 02 increases the rate of respiration of fruits yet it prolongs the "holding mp" period. This may be accounted for by the fact that the total gain in arount of COR given off in 5 months amounts to only 4.292 grams per 100 grams of fruit orer the amount given off in the atmosphere of air. 

As the rate of regpiration decreases as the terperature is lowered, it will readly be seen that, at jov $\mathrm{a}$. , the difference in the rate of respiration caused by forced ventilation or an excess of 02 being supplied rould have no marled effect on decomposition of the fruit. The same conclusion will also hold good in force ventilation of refrigerator cars to prevent "ice scald".

While working out the cietails of the apparatus and perfecting it's runing, pears were used in the respiration chambers. Due to the necessity of constantly naking mechanical changes in the duparatus, no ciefinite and concise figures can be given. On the whole the ork with pears showed a marked increase in the amount of coz given off while in an atmosphere of 02 as checked with the ones in the atmosphere of air.

With the present apparatus, fig. I, it will be possible to go into detail on the rate of respiration as effected by different gases, by temperature, by light, by-wrapping, by coating with an insulator, etc., of various fruits and any stage of their developement.

3. - $\quad$ COHCLUSIOIS.

1. In an atmosphere of 02 respiration is increased. Inaicating that some of the 02 is used in the process of respiration. 2. Iro indications of increased decomposition mere noted. This corresponds to the results obtained in the first part of the work. 3. The grin in the rate of respiration caused by an excess of 

02 when forced ventilation of storage plants and refrigerator cars is used would be so small that, as a freventative of "ice scald", they could be used without effecting the fruit. 

III COIOR AND ITS CORTELATION WITH THE ACIDITY OF AN APPLE.

In this brief work on the color of apples it was sought to determine whether or not there vas a definite correlation between the intensity of colcr of the epidermis and the per cent of aciaity of the meat. Is there a difference in the aciaity of the meat of a light colcred apple and a arark colored apple within the same variety which corresponas to the degree of coloring? And is there a cifference in the aciaity of the meat on the different sides of an individual apple which is colored on one side and not on the other? And, lastly, is the re a color substance present in the epidermis which aepenas in part or altogethe $r$ upon the per cent of aciaity as to whether it is developed in the epidermis?

1. NETHOD OF EXTRACIION OT COIOR.

The color was extracted by neutral alcohol. The apples were peeled as thin as possible and placed in a 50 c.c. measuring flask. Alcohol (95\%) was adaed and the flasks markea and left on a $70^{\circ} \mathrm{C}$. hot plate for twelve hours, then removed and the contents brought up to 50 \& ?

2 . REDUCTION NETHOD.

The reduction metroa used by Shibata, Kagia and Kishida, Jor. of Bio. Ch. 28, No.1.(1916) was usea. 5 - 10 ce of the alcohol extract was acidifiea by 

adding 5 - 10 drops of Conc. 프 Cl. A fer cc of the acidified extract were placea in a test tube rith a dron of mercury the size of a pea and a little magnesium powder, according to tne method of Shibnta.Magri and Kishida. Reâuction took place auickly with generation of free hidrogen and the production of a well defined pink color.

It was later found that the color was producea by प CI so that all. was needed was the adaition of a few drops of con. E Cl to develope the color of the alcohol extract.

3 . TEST FOR ACIDITY OF NEAT.

The aciaity of the flesh was tested for by taking 10.cc. of the meat and placing it in a 50ce. measuring flask and a $95 \%$ solution of neutral alcohol. After remining on the $70^{\circ}$ hot plate for 12 hours the contents was brought us to $50 \mathrm{cc}$. and the aciaity tested by titration with $10 \% \mathrm{IT}$. $\mathrm{KOH}$ with phenolphthalein as an inaicator.

The varieties tested for the acidity and color correlation and results are oriven in the table No. IV. The acidity is given based upon 1 as the acidity of the light apples in the ratio.

\section{TABIE IV. CORRELATION OF COLOR AIND ACIDITY.}

Variety.

Ratio of the reidity.

Relative color (Light apples) (Dark apples.)

Unknotrn

Wine Sap

Ben Daris

Jonathan

liinkler

$\begin{array}{ll}1 \% & 1.5 \% \\ 1 & 1.35 \\ 1 & 1.2 \\ 1 & 1.1 \\ 1 & 1 .\end{array}$

Color same(Light pirk)

피 did not chenoe 

No difference in the acidity of the light and dark sides of inoiridual apples could be detected tho the color was present in both sides arc gave a pink color with मCl of the same intensity with the individual apple.

4. - EFFECT OF IRYIIIG UPOH THE COIOR OF THE PEEIING OF

AN APPLE.

The peelings of several apples vere aried in the drying oven described in the following pages. Peelings from light and dark apples were dried as were equal weiphts of the light and dark colored epidermis of inaividual apples. During the process of drying, the color of all of the samples darkened slightly. However, when dipped in a 1\% sol. of salt just before drying, the color did not change when aried.

All of the varieties used in the acidity test were used except the Kinklers. In all of the smples the color corresponded to the color obtained in the same variety before drying.

5. - COMCLUSIOIS.

1. There apparently is a ciefinite correlation between the percent of acidity and the intensity of color developea in apples vithin a given variety.

2. Iro corresponaing variation in the percent of acidity of the flesh, on the light ana dark colorea side of an apple, was found. Howerer, with the limited amourt of work cione on this phase, no positive statement corcerning this can be made. 

3. The coloring substance of the apple is present in

all parts of the epidermis but unevenly developed for some unknown reason.

The above work is a mere introduction into the possibilities of further work along similar lines. As cleft ärafting, for instance, of a vellow variety upon a red variety will still give yellow colored fruit, it is evident that the color characteristics are present and function within the fruit to give it its color. Is there any correlation between the acidity of light and deep green colored foliage? Does there exist a correlation between the acidity of foliage ard the acidity of the fruit vithin a variety, or between different varieties? And can the acidity of the foliage be taken as a criterion in determining the acidity of the fruit a giren tree will boar, ana would this tell to what extent the basic color, almays present, will develop? These are only a fow of the many problems suggested by the brief work reported on color of the epidermis of apples ano it's correlation with acidity of the flesh. 



\section{IV. - EFFECTS OF DRYIIG OI APPLES.}

The work on drying of apples was cone to see if there was a change in the acid content, caused by the drying. Also, it was hoped that a method of crying, whereby the riacoloring could be prevented wi thout the bleaching with sulphur, might be found.

The apparatus used was a hand made aryer, devised and built for the occasion. The drying chamber consisted of an upright box $5 \mathrm{in.}$ by $6 \mathrm{in.}$ by $5 \mathrm{ft}$. long. The fruit ras placed on twelve remorable wire shelves set at equal distances in the box. One entire side of the box could be opened as shown in Fig. III. The air was heated by passing thru a pipe, heated by a gas burner, then the air enterea at the bottom of the aryer, passed thru the shelves, anä out at the top. The temperature coula be regulated by the flare or by the amount of cold air pas ing into the $r_{w}$ ted pipe. The bottom temperature was kept at $85^{\circ} \mathrm{g}$ and the top at $55^{\circ} \mathrm{C}$, when fruit $\mathrm{wrs}$ in the dryer. Tren fil ed with fruit, the temperature dropped betwe : $0^{0}-25^{\circ} \mathrm{C}$. All the material to be aried was first placed at the $t_{v_{1}}$, the dryer, then, as it aried, Iowereà to the bottom shelf, one shelf at a time. If placed on the lower shelves at the start, the fruit bakea before arying.

The effect of drying upon the color of the apples was juaged by comparison with the fresh fruit. 

The aciaity was determined as in the worle previously discussed on the correlation of acidity with color in an apple. 1. - EFEECT OF DRYIIIG II IIG TI, DARK, AIID SUILIGHT UPON COLOR. Wine sap apples were cored. peeled and sliced in circular slices as rearly the same thickness as possible. Samples of each apple were aried in the following ways; By placing in the sun out of doors: By artificially drying in the dark; And by artificially drying in the light. The color of the samples äried in the light aro dark vis the same, being slightly browned. The samples dried in the sunlight were very much browner than the other two. Then first placed in the sunlight. the apples bleached and had all the appearance of sulthur treated samples, but the color soon changed, upon further arying, until a brown color had appeared. This cheneing of colors was doubtless due to some photochemical change, or change aue to the presence of surlight. 2. - DFFECM OF DRYING UPON ACIDITY.

Two samples of equal weight each of six spitzenburg apples were taken, one sample was testea for the aciãity. While fresh, and the other sample was arried and the acidity tested and recorded. In each case, the moisture percent of the aried apple was found.

The figures oiven below were determined on the basis of the acidity of the fresh samples. The acidit of the fresh 

apple is taken as 1 in the table ard the acicity of the corresponcif a aried samples, figured on this basis in the ratio. TABL 1 RELATIVE ACIDITY OF FREST AID DRIED APPLI.

(Spitzenburg apples in bad, .ilted concition.)

No. of apple smple. Acidity of fresh flesh. Aciaity of dried.

$\begin{array}{ll}1 & 1 . \\ 2 & 1 . \\ 3 & 1 . \\ 4 & 1 . \\ 5 & 1 . \\ 6 & 1 .\end{array}$

.58

.58

.715

.56

.55

.534

In this table, it is seen that aried to a moisture content of $9 \%$, the total acidity of the se spitzenburg apples decreased almost one half. These results were not varified by further experimental work, thus, the varrant no conclusion, as to the exact effect of arying upon the aciaity of apples in general.

3. - SOAKING FOR SOITMIIZ III TATER BETORE DRYIAU.

Apples were prepareò as described nbove, then half the samples were soaked in water for two hours, before arying. Each shelf in the aryer contained the same number of soaked and untreated slices in order that the temperature would be the sare on both the treated and untreated samples.

The untreated slices dried to a moisture content of 17.4\% while the treated ones driea to $22 \%$ moisture. The treated apples aried out much thinner than did the untreated ones, indicating that the soaking, previous to aryizo, had caused some physiological change in the cell structure, so that when the 

moisture was removed by evaporation, the cells collapsed or shrunk up more than the cells in the untreated did. 4. - DIPPET IN SOI. OF SALT AND SUGAR BEFORE DPYILIG. Slices were dipped in a $1 \%$ sol. of salt, before arying, then dried with checls from the same apple, as in part three above. The color vias slightly lighter in the ones dipped in the salt sol. before drying, than in the ones untreated. The salt did not taste, after drying.

Dipped in a 10\% sol. of salt, before arging, the aried fruit retained the original color but tasted strongly of salt.

Dipping in a 1\% seccharose solution had the same effects as dipping in a $1 \%$ sol. of salt.

Dipping in a 10\% sol. of saccharose dia not give quite as good results, in prevention of color, as aid the 10\% sol. of salt, there being a slight browning.

Povdered saccharose was surinkled over the slices of apple just before placing in the crying oven. As a result, a brittle, aried candied apple was obtained. The orioinal color was obtained and a very sweet taste was resent.

Dried samples were taken and owderea in a mortar and placed in small bottles and the bottles sealed. The powder obtained from the untreated fruit was a shade yellower than the powder from the treated samples, but no difference in the shade 

of coloring could be distinguished between the wowaers obtained from the samples treated in the various ways aescribed above, before drying.

In each case, where the fruit was dipped in a sol. of salt or sugar, the moisture content was higher than in the check, as shown in the following table:

TABIE 2 EFIECT OF SUGAR AND SAIT SOL. ON \% MOISTURE.

ireatment.

$1 \%$ salt sol.

Check

$10 \%$ salt sol.

Check

$1 \%$ sugar sol.

Check

$10 \%$ suger sol.

Che ck

Joated with powdered saccharose Check
\% lioisture.

$9.4 \%$

8.9

6.2

5.4

5.4

$4 \cdot 6$

3.0

2.5

6.4

4.2

The presence of the concentratea solutions on the surfaces of the fruit, while orying, must have inhibited the free passage of the moisture from the cells, thus holding the final moisture content hipher than in the ciriea untreotea fruit. 5. - MOISTURE ABSORBIIG POUIR OF DPIEI APPIES.

In or der to find approximately how much moisture dried apples would absorb from the atmosphere, if left exposeả, a weighing bottle was filled with a sample aried to 12\% moisture. The top vas left off of the bottle and care taken that no dust, or foreion matter might get in, the top being replaced while weighing. The following table shows the rate, 

and amount of moisture taken up by this sample of dried wine sao apples:

TABLI 3 IRIED APPLES EXPOSED TO MOISTURE OF THE AIR.

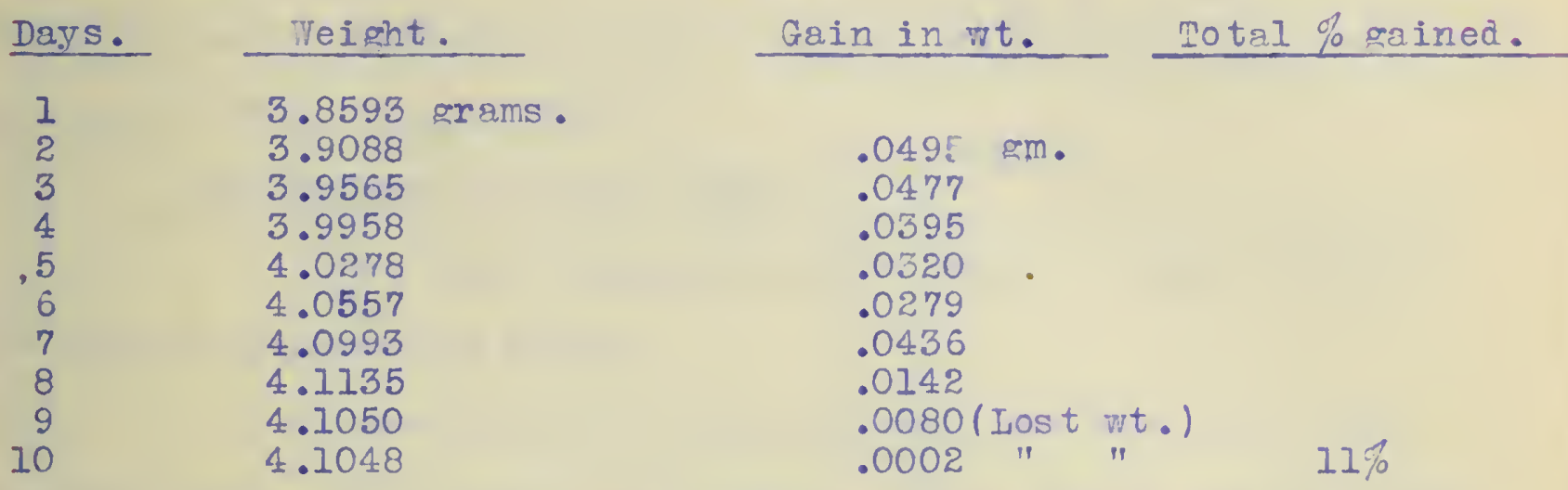

Enough moisture had been taken from the air in ten days, at which time the absorption had stopped and the weight was fluctuating with the amount of moisture in the air, to bring the original moisture content (12\%) up to $23 \%$ or an increase to $11 \%$ moisture. Commercinlly, apples are dried to a $27 \%$ moisture content, that beino the standard.

It is certain that apples äried to a low moisture content can not be left exposed to the air for any length of time, as they will absorb enough moisture to spoil the ir keefing qualities. The capacity for taking up molsture of fruit treated with salt or sugar sol. before drying, was not determined.

\section{DRIED APPIES PIACED IIT OII PAPER BAGS.}

The bags were made from the oil-paper used in packing cut flowers and was sealed by using a hot iron and paraffin. 

salt and sugar sol., previously discussed, were sealed in the bags and left on the laboratory table. The oil paper did not keep out the moisture of the atmosphere and the material in the bags gradually toak up moisture. After two weeks, they were no longer brittle, but leathery.

7. 1 . CONCLUSIONS ON DRYIIG WORK.

Artificial drying does not ceuse as much browning as the old sun-drying method.

In one specific case the per cent of acidity decreased during the process of drying. This result has not been varified by further investigation.

3 . Soaking in water for two hours before drying had no effect upon the coloring of the apples brown while drying, but seemed to have affected the cell structure of the apple as shown by a decrease in volume as compared to the untreated check, dried with the treated apples. The soaked apples vere also more difficult to dry as they retained the cell moisture longer than the fresh apples during the process of drying. 4 . Salt or sugar solutions of various dilutions, precerve the original color while arying but the y also increase the moisture retaining power of the aples. The use of sugar is doubtless more profitable from the commercirl standpoint than salt as it counteracts the aciaity of the fruit which would cause less sugar to be required upon cooking.

If the price of roduction is not prohibative, the re 

is no reason why there could not be dried apples wut on the market in powdered form, as onions are, to be used as seasoning etc. Dried apples could be put on the market in sealed packages, as numerous breakfast cereals are at present, with the original color and flavor and in brittle, floke form, Sweetenea properly during the process of arying, they would make a very desirable dish. 

DF.SAUSSUPE. An. chin. phys. 1 1821/12-143-225 reported that green fruits acted like le res in their usage of air. 02 disappeared in the daytime and cirbon dioxide appeared, then at night the reverse occured, whe: exposed to sunlight the fruit gave off vart of the 02 of the CO2 absorbea in the dark and usea up $x 11$ of the $C 02$ in the atmosphere surrounding them when enclosed in a vessel. He found that green fruit could remove as high as $7 \% \mathrm{coz}$ from the air when artificially supplied with it. FREYY Comp. rend. (1844) 19;784. Torized extensirely on green fruits on the tree. He varnished the epidermis of the fruits, thus cutting off respiration. H found that growth stopped when varnished and then an andysis of the air in the fmuits was made from which he thought that he had founo a ferment which was the cause of the respiration of fruits. IECHORTIER AID BEIIANY Comp. rend. (1869) 69; 356.466. sealed apples in jars for a long period then examined. They found much CO2 had been given off, alcohol had been formed and Jeast cells were present in the parenchyma calls, thus showing that $\mathrm{CO} 2$ was given off in respiration and that a lcohol was formed in the process of decomposition in enclosed jars. SAINTPIEPRE \& MAGIIEN Ann.agro.-(1878) 4,161. S1owẻa that fruit gave off $\mathrm{CO} 2$ in light and dark both. That H2O was taken up or given off according to whether the fruit was in a wet or ary place. They maintained that the sugar and acid was 

carried to the eruit thru the stem and the acid was later used in the process of respiration. That CO2 vas given off as end product of respiration was established.

$$
\text { A. H. Benson Agr. Gaz. N. S. Wales 4, (1893) } 11 .
$$

drew the conclusians from his results on cold storage vork, that reaches kept best at a temp. of 41. m $^{\circ} \mathrm{F}$. with high ventilation to prevent accumulation of $\mathrm{CO}$ which he held caused the rate of "breaking down" to increase. And that freestones could only be kept in cold storage for two weeks while clings could be kept for a month.

GERBEP Annales des Sciences naturells; 4;1(1896)8. found a decrease of 02 and an increase in the amount of 002 arounc unripe fruit after 24 hours of enclosure in a container. He enclosed some fruit on the tree but it failea to mature. thus he concluded that the 02 of the air was necessary for ripening of fruits on the tree. He tried experiments with various gases on fruit on the tree but got no results as he kept the fruit enclosed all the time and gromth ceased.

\section{LOISEAU Paris Iibrairie et Imp. Horticolas (1903)} 31. Using a temperature of $0^{\circ} \mathrm{C}$ he found that 600 peaches kept in good shape for four weeks. After 35 - 40 àays $10 \%$ had deteriorated. Two months, $75 \%$ had deteriorated and that vrapping did no good. Also he stateà in his conclusions that storage peaches held up 7 days on the marliet while fresh ones only held up 3 days. The statements as to wrapping are disproven by the present work. 

II. A. BLAKE \& A. J. FARLEY if. J. Str. Rept. 1911.

tested the storage qualities of several varieties of peaches and found that early varieties broke down first and that the Elberta "stood up" best in storage. They attribute much of the failure to store peaches to lack of proper spraying to kill the fungi before storing instea of the natural processes of aecomposition of ripe perches.

BICFT,OIT-U.S.B. of Ch. 94. found that storage had little effect apon the sugar, starch and acid content of apples. attributed ice scald to chemical changes within the apple or fruit and not to exterral conditions alone as accumulation of $\mathrm{CO} 2$ or high moisture content of air.

BIGELOT - U.S.B. of Ch. 97. Studiec four periods of the peach. After June àrop; hard; marl et ripe; ully ripe. He found no starch in the first two perions. From stone hard to ripe the weight increased four times and the pro ortion of flesh to stone increased fire times. From June drop to ripe the weight increaseà eight times. Sugar decreased ard the acid increased. He gives tre composition of peaches as; flesh $92.51 \%$, stone $7.02 \%$ and kernel .69\%.

G. H. PONELI. B.P.I. BuIl.40. reported that peaches kept in cold storage at $2 \varepsilon^{\circ} \mathrm{C}$ kept perfectly for 2 weeks and "hela up" on the market for $2-3$ days after being taken from storage. When stored after ripe, peaches deterioratea faster than when put in harà ripe. Under higher temperature, deterio- 
ration was more rapid. Wrapped pears kept better and ripenec more slowly than unvirappeà pears. Double wrappers gave better results than single wrappers with vears. No $i$ scald occured.

$$
\text { G.R. IIII. Jr. Cornell bull, } 530 \text { reported that }
$$

the hardness of the peach is due to pectose una that "breaking down" is the changing of the rectose to pectin. He found that in an atmosphere of $\mathrm{n}$ itrogen $\mathrm{h}$ yorogen or $\mathrm{CO} 2$ green peaches, medium ripe jeaches anả ripe peaches lost their flavor and colorea badly. That the softening of the ripe peaches was retarded by an atmosphere of $\mathrm{CO} 2$ and slightly retarded by N2 and H2. This respiration work was carried on with an apparatus somewhat similar to the one used in the experimental work given in this paper on the respiration of apples in an atmoshere of oxygen.

THATCPER Jr.Agr.Res. 5, (1915) 103.t ried to seal fruit in a coating to prevent gaseous exchange but failed. He sealed apples in jars containing atmosphere of the following gases; oxygen, air, hyärogen, nitrogen, carbor dioxide and sulphur aioxide. He found that the c02 checked the breaking down processes, which effect he attributed to the fact that 002 is an end product of the chemical changes in the ripening processes of an apple and an excess of an end product retards the action of the enzyme causing the reaction in proportion to the increase of the end product. He could f: 2 no invertase present in an aple tho he founa invert sugar present. All enzymatic 
changes of the carbohydrates were attributed to oridases only. EDGAR RICHARDS Peport Com. Agric. for 1886, Tash. D.C. reported work dane on 17 varieties of apples before and after drying and that only slioht chemical changes took place during drying.

\section{C.A. BROTNE Penn. Dep't Agr. Bull $58.1899 \mathrm{pub}-$}

lished some mork on the chemical composition of the apple and it's products. Copies of this work and the work of Richards were not obtainable by the writer.

The only other work relative to the chemical changes in fruits caused by arying, available, was the work on prunes done by G. W. Shaw of the Oregon Agr. Station and reportea in bulletins $45(1886)$ and $61(1897)$. In these bulletins he deals mostly with the practical ana commercial side of the drying of prunes and the analysis of fresh pranes. The only analysis of dried prunes given by him is preceded by a statement which emphasizes that it is only preliminary work and would be varified later. He dravs no conclusions nor comparisons of the chemical changes crused by drying.

There is an abundance of literature available on drvers, eraporators and various phases of the mechanical side of drying and evaporation but practically no work has ever been reported on the chemical side of drying and evaporating. 

SHIBATA, MAGAI AIND KISHIDA; Jor. of Bio. Ch.XVIII, Dec. 1916. In this work on the presence of flavone in plants, they found that the mother substance of the red pigment(chromogen) was present in the white flowers of the Disrvilla. Almost all kinds of white flowers containe flavone or flaronol glucosides. it being a common occurence in plant tissues also, localized chiefly in the epidermis and periuheral layer of the aerial part of the plant.

They concluded that flavone functioned as an absorbent for the ultra violet-rays of the sunlight, preventing them from injuring the living protoplasm and its biochemical agencies. They also thought thet flavone played an important role in the processes of respiration. The formation of anthocyanin was supposed to be a simple biochemical reaction; a reduction of the already existing flavones.

In aiscussing flarone, they state that it depends upon sunlight for it's derelopement and that there is no appreciable loss of flavone by drying the specimen. 
Figure I. Respiration Apparatus

A - Constant level bottles.

B - Pressure or gas bottles.

C - $\mathbb{Z}$ OH bottles.

D - iater traps.

I - U tubes.

F - Potash bulbs.

G - Respiration chambers .

H - Platform

I - Support for U tubes.

$J$ - Thermometers.

$\mathrm{K}$ - Agitator.

I - Wash bottIes.

$\mathbb{N}$ - Regulator.

o - Belts from motor to pump and agitator.

U - Notor.

T - Fump.

Fipure II. Cross section of ore section of respiration apparatus

C - Potash bulbs.

D - U tubes.

$E$ - Support for U tubes.

F - Nater trap.

I - Respiration chamber (desiccator)

J - Fruit.

$x$ - Rods for holding desiccator in place in hot water bath.

Ii - Wash Bottle.

II - Intake of gas from gaw mail.

o - Gas tubes leading to other tro desiccators in this series.

P - Glass stop cock.

Figure III. Drying Apparatus.

A - Outlet of air from drying chamber.

B - Drying chamber.

C - Iron pipe heated by burners.

D - Gas burners.

$\mathrm{E}$ - Air main.

F - Removable wire shelves.

G - Door to aryer. 



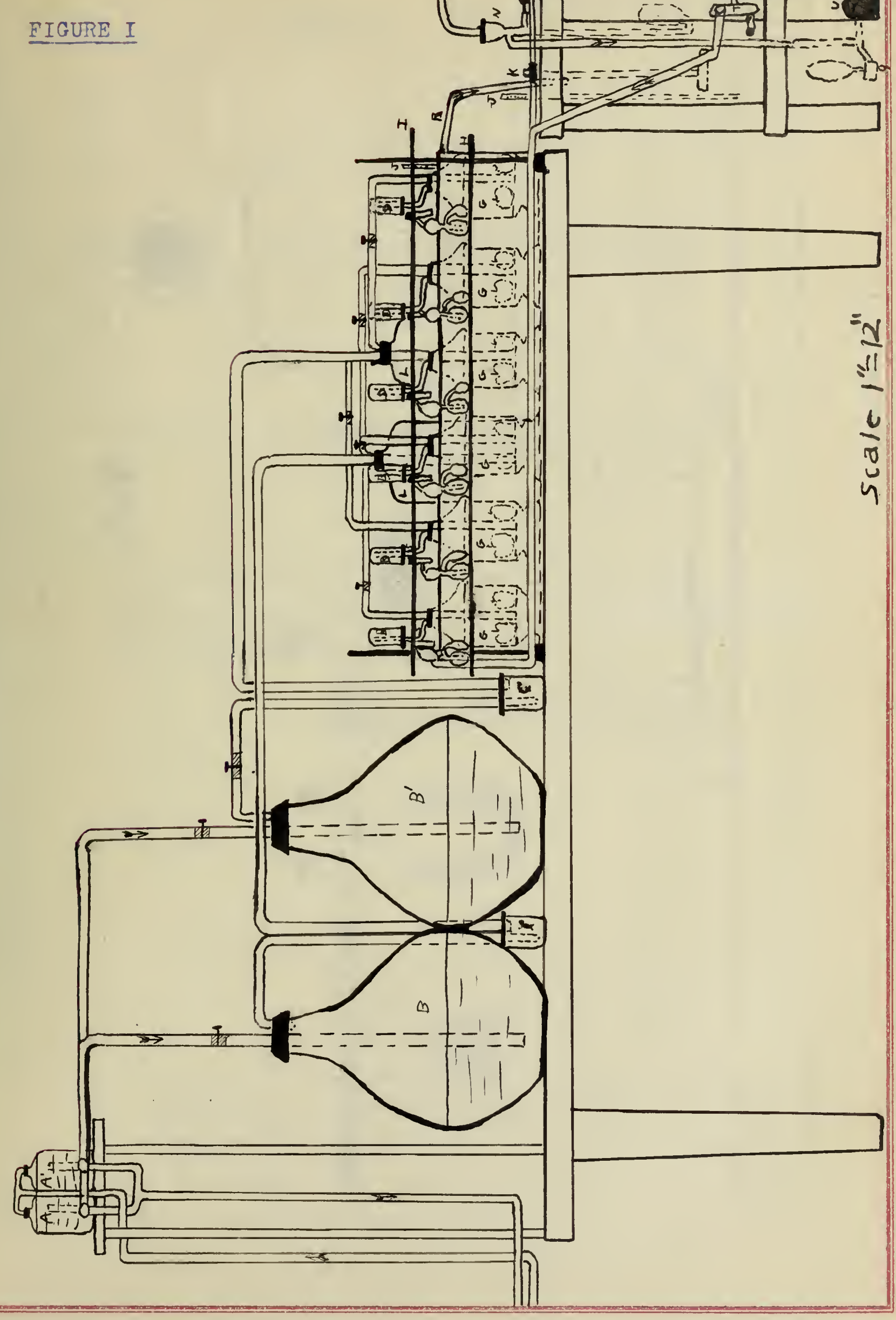





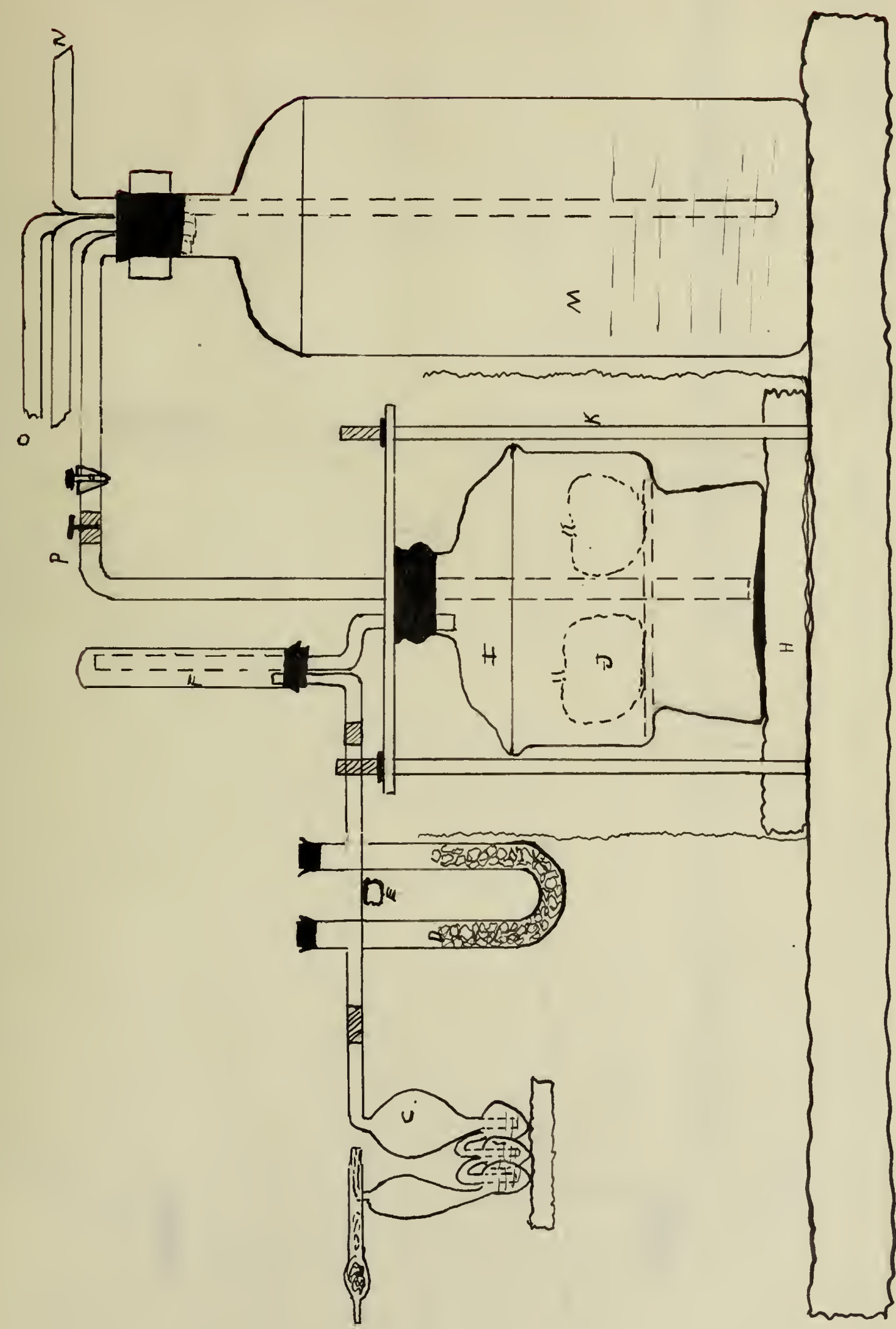



FIGURE III

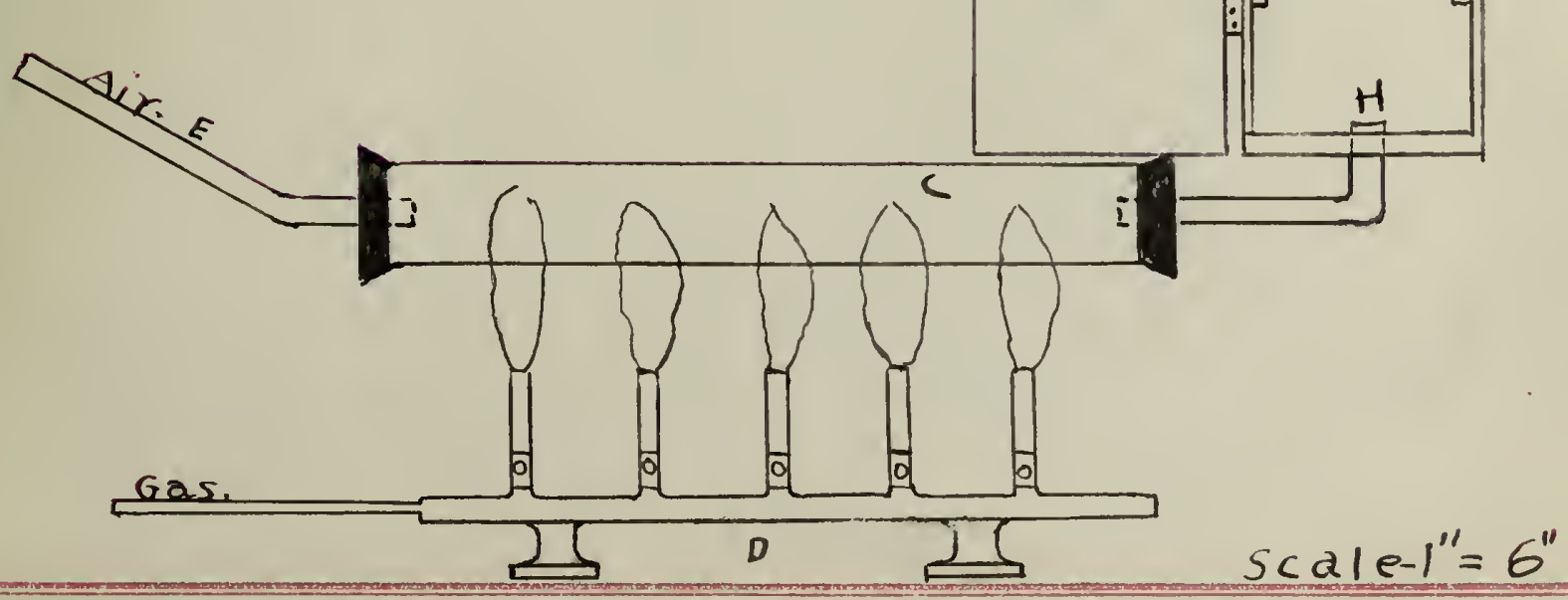



UNIVERSTTY OF ILLINOIS-URBANA

30112082199222 